\title{
Dédalo en los mosaicos romanos
}

\author{
M. PILAR SAN NICOLÁS PEDRAZ
}

\section{RESUMEN ABSTRACT}

En este trabajo se analizan los escasos mosaicos del mito de Dédalo, cuya importancia radica no sólo por su excepcional ternática, sino por el

tratamiento iconográfico de las escenas representadas, narradas por los diferentes mitógrafos grecorromanos. Dentro de ellos, la composición del pavimento de la colonia Lucus Augusti muestra una serie de anomalías artísticas e iconográficas, que la diferencian de los

restantes, como el tratamiento “abreviado" en el que a través de unas cuantas imágenes se intenta contar varios episodios del mito, $y$ sobre todo la presencia del laberinto.
This report deals with the few number of mosaics of the Daidalos mith, which is important not only because of its excepcional thematic but by the iconography of the pictures represented, narrated by some grecoroman mythographers. Among them, the composition of the Lucus Augusti colony flooring shows a series of artistic and iconographic anomalies that makes the difference from the rest, like the "abridged" treatment, in which through several images, there is an intention to narrate some episodes of the mith and above all, the presence of the labyrinth.

Según la tradición mítica Dédalo fue miembro de la estirpe real ateniense, del cual existe diversas genealogías, para algunos autores le consideran hijo de Alcipe y de Metión, uno de los hijos de Erecteo (Apol. III 15, 8; schol. Plat. Ion 121 a; Tzetzes Chil. I 490), para otros de Eupálamo o tal vez de Palamaon (Paus. IX 3, 2). La mención literaria más antigua de 
Dédalo aparece en el canto XVIII, versos 590-592, de la lliada de Homero, en el que se hace una comparación entre el escudo de Aquiles y un chorós que construyó en Cnosos para Ariadna. Fue el prototipo del artista universal, ingenioso, arquitecto y escultor, atribuyéndosele diversas obras arcaicas así como las estatuas animadas a las que se refiere Platón en el Menón $(97,2)$ o las agalmata, estatuas representando a los dioses (Apol. III 15, 18; Hig. fab. 274). Trabajaba en Atenas con su sobrino y discípulo, cuyo nombre según algunos mitógrafos era Perdix (Hig. fab. 244; Ovid. Metm. VIII, 236-259) y para otros sería Talos (Apol. 15, 9; Diod. Sicul. IV, 76); sin embargo el día que el joven, inspirándose en la mandíbula de una serpiente, inventó la sierra (Ovid. Metm. VIII, 240) -aunque para Plinio fue el propio Dédalo quien la ideo-, el maestro, inducido por la envidia profesional, le mata arrojándole desde lo alto de la Acrópolis, por lo que tuvo que comparecer ante el Areópago, siendo condenado y desterrado de Atenas (Schol. Eurip. Orest. 11643; Apol. III 1, 4; 15, 9; Hig. fab. 39, 244; Ser. Ad. Aen. VI, 14; Diod. Sicul. IV, 76).

Dédalo se marcha a Creta (Paus. 121,$6 ; 126,4)$, donde es acogido por el rey Minos, hijo de Júpiter y Europa (Hom. II. XIV 321; Plat. Min 318; Eur. Cret.frag. 475; Diod. IV 60; Nonn. Dion. I 355), llegando a ser su arquitecto y escultor (Paus. VIII 53, 8). En la isla, Pasífae, hija de Helios, hermana de Eetes y de Circe, y esposa de Minos, se enamora de un toro, como castigo de Poseidón a Minos por haber incumplido un voto solemne (Apol. III 1, 4; Diod. IV 77, 1-2) o de Venus por haber descuidado sus sacrificios (Hig. fab. 40) o por el rencor que tenia la diosa a la descendencia de Helios desde que éste delató a Hefesto su adulterio con Ares (schol. Hippol. 47; Servio Bucol.VI 47, y Aen.VI 14, 24 y 26). La reina cretense para conseguir sus deseos amorosos recibe la ayuda de Dédalo, quién le construye una vaca de madera, recubierta de una piel de vaca auténtica, en cuyo interior se introduce para consumar la bestial unión amorosa de la que nacería el famoso Minotauro (Apol III 1, 4 y III 15, 8; Hig. fab. 40; Diod. Sicul. IV 77, 1.5; Zenob. IV 6). Aunque existe otra variante que indica que el toro era Zeus metamorfoseado (Serv. Bucol. VI 46)

Minos avergonzado de la infidelidad de su esposa manda construir a Dédalo el Laberinto para encerrar al Minotauro (Apol. III I, 4; Ovid. Metm. 157-161), aunque para Higino ( fab. 40) es iniciativa del artista para ayudar de nuevo a Parsífae. Cada nueve años le daba a devorar al monstruo siete jóvenes y siete doncellas, macabro tributo de Atenas a Minos que fue establecido después de su victorioso asedio de la ciudad y del asesinato de su hijo Androgeo. Un día entre los muchachos llegó Teseo a Creta, decidido a dar muerte al Minotauro. Ariadna, hija de Minos y Pasífae, se enamora del héroe y para ayudarle en su empresa le entrega, aconsejada 
por Dédalo (Schol. Hom. Od. XI 322; Schol. Hom. II.XVIII 590), un ovillo de hilo para que no se perdiese en el Laberinto y poder matar al monstruo. Después de realizar la hazaña Teseo, junto a los jóvenes y muchachas que aún no habían sido entregados al Minotauro, emprende el regreso a Atenas llevándose consigo a Ariadna. Hacen escala en la isla de Naxos y allí se produce el célebre episodio del abandono de Ariadna, dormida, por Teseo (Apol. Ep.I 9; Plut. Tes. 20; Paus. I 20 y X 29, 4; Ovid. Met. VIII 174 ss.; Her. X; Hig. fab. 43; Catul. LXIV 116 ss.; Erat. Cat. 5).

Dédalo no tarda en sentir la ira de Minos que le detiene en la isla de Creta (Ovid. Met. VIII 183 ss.); según algunos mitógrafos por la ayuda prestada a Pasifae que posteriormente le libera (Diod. IV 77; Hig. fab. 40); para otros la causa fue por ayudar a Teseo y Ariadna (Apol. Ep. I 12; Schol Hom. Od. XI 322). Le hace encerrar en el Laberinto junto a su hijo ícaro, que según señala Apolodoro $(\mathrm{IX} 11,4)$ había tenido con una esclava de Minos llamada Náucrate. Dédalo decide huir por los aires, y fabrica, para él y para su hijo, unas alas, cuyas plumas están sujetas con cera (Hig. fab. 40), cola o pegamento (Apol. I, 12-13; Zenob. IV 92) o con cuerdas (Ovid. Ars. II, 21-96; Metm. VIII, 184-235), se las colocan y emprenden el vuelo. Ícaro, orgulloso con el nuevo invento, desatiende las advertencias dadas por su padre y se acerca demasiado al sol, se le despegan sus alas y cae al mar, junto a la isla Dólique, que desde entonces, según Apolodoro (II 6, 3) y Pausanias (IX 11, 4-5) se la denomina Ícaro o Icaria. Otra versión sitúa la huida por mar en un barco de vela, pereciendo ícaro en un naufragio (Paus. IX 11, 4-5; Diod. IV 77, 5-6). En una u otra versión literária el trágico final de Ícaro es su muerte. Posteriormente, Dédalo continua su viaje, existiendo también diferentes versiones del lugar donde se refugia. Para algunos autores, siguiendo la tragedia de Sófocles, Los Camicos, llega a la ciudad de Camico, Sicilia (la actual Agrigento), siendo acogido por el rey Cócalo quien le protege de Minos, y allí se produce el episodio del invento de Dédalo de pasar un hilo a lo largo de la espiral de la concha del caracol ( Ovid. Met. VIII 260; Hig. fab. 40, 44; Eust. Ad Iliad. XVII 220; Schol. Pind Nem. IV 95; Schol. Homer. Iliad. II 145). Para Plutarco volveria a Atenas (Tes. 19), y según narra Virgilio (Aen. VI, 14 ss.) llegaria hasta Cumas, donde consagra en el templo de Apolo sus alas ${ }^{1}$.

La primera secuencia de la historia referida en las fuentes literarias, que situaría a Dédalo en Atenas es poco frecuente en el arte antiguo, la

G. BeCATTI, La leggenda di Dedalo, Rom. Mitt. LX-LXI, 1953-1954, 22-36; F. Frontis! DuCroux, Dédalo. Mythologie de l'artisan en Grèce ancienne, Paris 1975; A. RUIz DE ElvIRA, Mitología Clásica, Madrid 1982; S.P. MonRIS, Daidalos and the Origins of Greek Art, New-Haven-London 1992. 
encontramos representada en cuatro documentos relacionados con la caída de su sobrino Perdix desde la Acrópolis, tres de ellos de identificación dudosa. En un fragmento de sarcófago, conservado en el Museo de Verona y procedente de esta ciudad ${ }^{2}$, se aprecia el momento anterior de ser arrojado Perdix desde lo alto de la Acrópolis, cuando ambos personajes, tío y sobrino, están forcejeando (Figura 1). La misma escena parece



Figura 1. Dédalo y Perdix en lo alto de la Acrópolis de Atenas. Fragmento de sarcófago de Verona.

2 T. RıाTI, Iscrizioni e relievi greci nel Museo Maffeiano de Verona, Verona 1981, 166, $\mathrm{n}^{\circ}$ 10; LIMC VII Perdix I, no 3. 
que se ha representado en un fragmento de camafeo calcedónico, de época imperial, que se conserva en el Cabinet de Médailles de Paris ${ }^{3}$ (Figura 2); mientras que en la pintura pompeyana (VI 7, 8) del Museo Nacional de Nápoles figuraría la muerte de Perdix ${ }^{4}$. Esta escena dudosa muestra en una procesión con varios artesanos trabajando en presencia de Athenea, diosa protectora de las artes, la figura de Dédalo que tiene a sus pies a Perdiz yacente, imagen esta última que también ha sido interpretada por su aspecto como una de las esculturas fabricadas por el

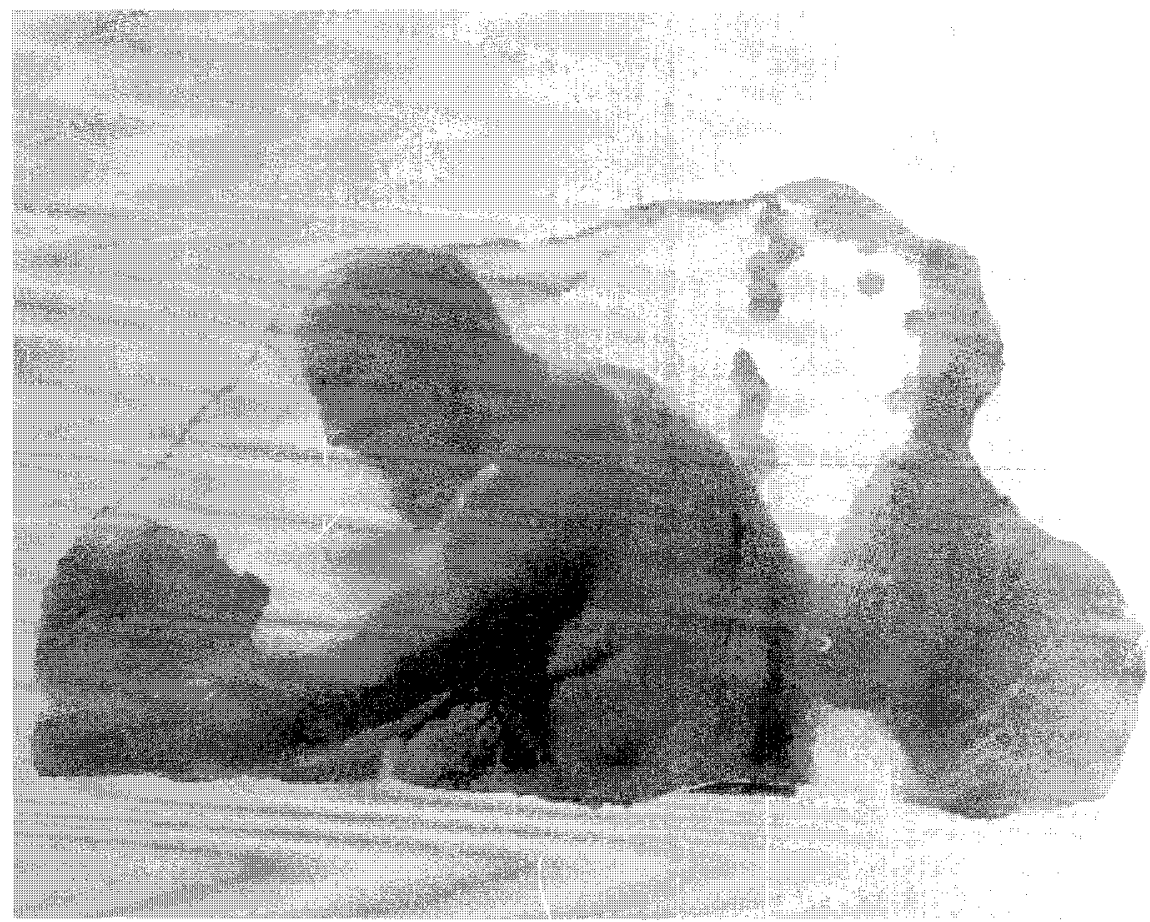

Figura 2. Dédalo y Perdiz forcejeando. Fragmento de gema. Cabinet des Médailles de Paris.

3 Para algunos autores sería Dédalo e Ícaro,sin embargo para J.K. Papadopoulos lo interpreta como Pasifae, Dédalo y el toro, cf. LIMC III, Daidalos et Ikaros, $n^{9} 30$; LIMC VII, Pasiphae, $n^{\circ}$ 37. Nosotros sin embargo creemos que por la actitud de ambos personajes forcejeando solo puede ser Dédalo y Perdix, mientras que el animal figurado detrás de Dédalo seria la vaca de madera en vez del toro, uno de los inventos del artista que fabricó para Pasífae.

4 S. ReInach, Repertoire des Peintures Grecques et Romaines, Paris 1922, 236, 4; K. SCHEFOLD, Die Wande Pompejis, Berlin 1957, 99; LIMC VII, Perdix I, n²4. 
artista (Figura 3). La caída de Perdix que le llevara al desenlace fatal, parece que se ha documentado iconograficamente en un lekitos ático, del siglo $v$ a.C. ${ }^{5}$, que se conserva en el MMA de Nueva York, en el que se ha figurado una perdiz cayendo, metamorfosis que se produce en el momento en que cae al vacío arrojado por su tío, y en el suelo una figura alada (Figura 4). Esta escena también dudosa, mostraría una contaminación con la secuencia de la caída de ícaro por lo que es difícil distinguir de que personaje se trata, Ícaro o Perdix?

Otros episodios de la historia de Dédalo tuvieron gran aceptación en el mundo griego, etrusco y romano como demuestran las numerosas representaciones de los relieves, cerámica, terracotas, pinturas, sarcófagos, monedas, bronces y mosaicos ${ }^{6}$. En ellas se hace alusión principalmente a

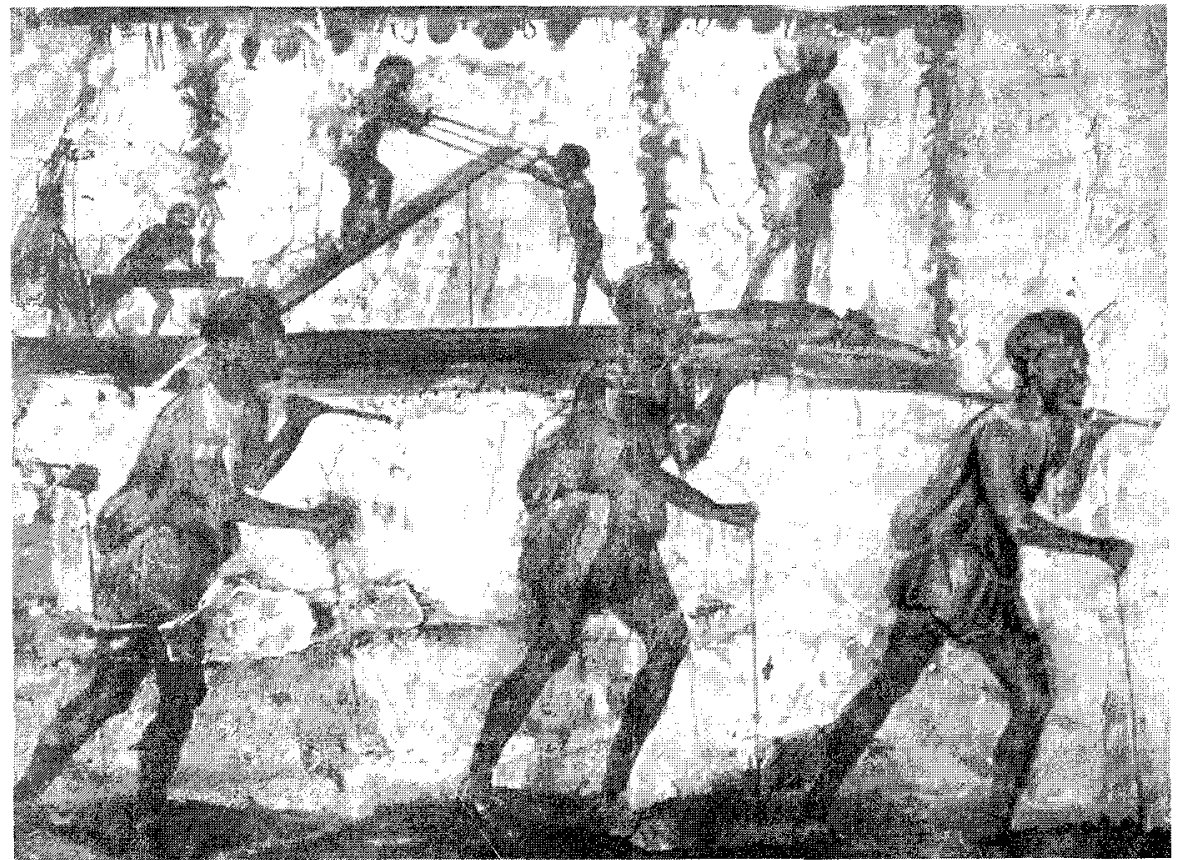

Figura 3. Dédalo y a sus pies yacente Perdix. Pintura pompeyana del Museo Nacional de Nápoles. 




Figura 4. Caída de Perdix?. Lekythos ático. MMA de Nueva York.

5 H. J. Rose, Icarus and Perdix on a Fifth-Cent. Vase ?, JHS 48, 1928, 9-10; EAA IV, 1961, 83, fig. 107; LIMC III, Daidalos et lkaros, $\mathrm{n}^{2} 47$.

Cf. LIMC III, Daidalos et Ikaros; LIMC VII, Pasiphae. 
dos secuencias bien definidas: Dédalo en Creta como cómplice de Pasífae; y su desgracia después del nacimiento del Minotauro, con la fabricación de las alas y su huida de la isla.

En la musivaria romana el mito de Dédalo no es desconocido, y aunque los testimonios más abundantes están relacionados con él a través de las distintas secuencias del mito de Teseo en el Laberinto y su lucha con el Minoutaro ${ }^{7}$, existen cuatro ejemplares con otras representaciones en las que de una forma más directa el protagonista es el propio artista. Dédalo confeccionando la vaca ha quedado plasmado en los mosaicos de Cartago y de Lugo; Dédalo ofreciendo la vaca a Parsífae se documenta en el pavimento de Macomades; la reina cretense, el toro y el Laberinto se figura igualmente en el mosaico de Lugo; Dédalo e ícaro también en el pavimento de Cartago; Dédalo solo en el mosaico de Henchir-Thinae. La cronología de estos pavimentos oscila entre los siglos III y IV.

El relato de Dédalo la vaca y Pasífae fue el tema preferido por los artistas etruscos desde el siglo IV a C. y por los romanos hasta el siglo $\mathrm{V}$, sin embargo, aunque fue tratado literariamente en la obra perdida de Eurípides, Los Cretenses, representada hacia el año 430 a. C., y por otros autores, no aparece figurado en el arte griego. El episodio se ha plasmado en tres mosaicos romanos con distintas versiones iconográficas. La escena del artista confeccionando la vaca aparece en el mosaico de los caballos de la Casa de los Caballos de Cartago, fechado a principios del siglo IV. El pavimento ostenta un esquema compositivo a base de cuadrados en donde los caballos, algunos identificados con su nombre, presiden los paneles junto a diversos temas mitológicos como Amazona, Aquiles, Dánae, Dioscuros, Eteocles y Polynice, Hércules, Hylas, Licurgo, Narciso, Orfeo y Pelops ${ }^{8}$. En el panel $n=53^{9}$ (Figura 5), detrás del caballo y en la parte superior derecho del cuadro, delimitada por una banda grisácea, se representa a Dédalo sentado en una roca, mirando hacia la izquierda, esta vestido con una túnica corta, exomis, atada en el hombro izquierdo; en la mano derecha porta un martillo corto y el brazo izquierdo lo apoya en una sierra que a su vez esta adosada a la roca. Delante del artista aparece la vaca de madera mirando hacia la derecha y, aunque no esta representada la plataforma con las ruedas que menciona Apolodoro (III 1, 4) como en las pinturas pompeyanas de la Casa de los Vetii (VI 15, 1p) (Fi-

\footnotetext{
W.A. DASzEWSKI, La mosaïque de Thésée (Nea Paphos II), Varsovia 1977; Cf. LIMC VI, Minotauros, no 51-54, 56-59; LIMC VII, Theseus, no 253-256.

8 J.W. Salomonson, La Mosaíque aux Chevaux de l'Antiquerium de Carthage, La Haye 1965, 31 ss..

9 ID., 122-123, fig. 57, lám. XLVI,1.
} 




Figura 5. Dédalo confeccionando la vaca. Mosaico de la Casa de los Caballos de Cartago. Panel nº 53. Foto in situ de G. López Monteagudo.

gura 6) o de la Casa de la Caza Antigua (VII 4, 48, 10) (Figura 7) ${ }^{10}$ y en el sarcófago del Museo del Louvre ${ }^{11}$ (Figura 8), sí figura la trampilla para que pueda introducirse Parsífae. Este momento de introducirse la reina en la vaca señalado por algunos mitógrafos, solo se aprecia en un oinochoe ático, que se conserva en el Museo Clásico de la Universidad de Tasmania, fechado c. 375-350 a.C. ${ }^{12}$ (Figura 9).

La forma de representar al artista sentado es típica de las diferentes versiones de Dédalo confeccionando las alas ${ }^{13}$, ya sea solo (Figura 10) o junto con su hijo Ícaro (Figura 11), pero en el mosaico de Cartago esta trabajando su otro celebre y anterior invento, la vaca de madera. El animal esta figurado entero, recordando el relato de Apolodoro (III 1,4) «que fue construido de un solo bloque» como se aprecia en una de las escenas

10 S. REINACH, op. cit. en nota 4, 183, 1 y 3; K. SCHEFOLD, op. cit. en nota 4, 181 y 145

11 Este sarcófago ilustra tres momentos diferentes del episodio de Dédalo y Pasífae : (de izq. a derecha) Pasífae encargando la vaca de madera a Dédalo, la construcción de la vaca, Dédalo ofreciendo la vaca a la reina cretense, cf. F. Baratte y C. Metzger, Musée du Louvre. Cataloge des sarcophages en pierre d'époque romaine et paléocrétienne. Paris 1985, 64-76, $n^{9} 22$.

12 R. Hood, Greek Vases in The University: A Short Guide, 1892, 34, nº 82.

13 Cf. LIMC III, Daidalos et Ikaros, $n^{0} 3-11 ; 23$ a-b. 


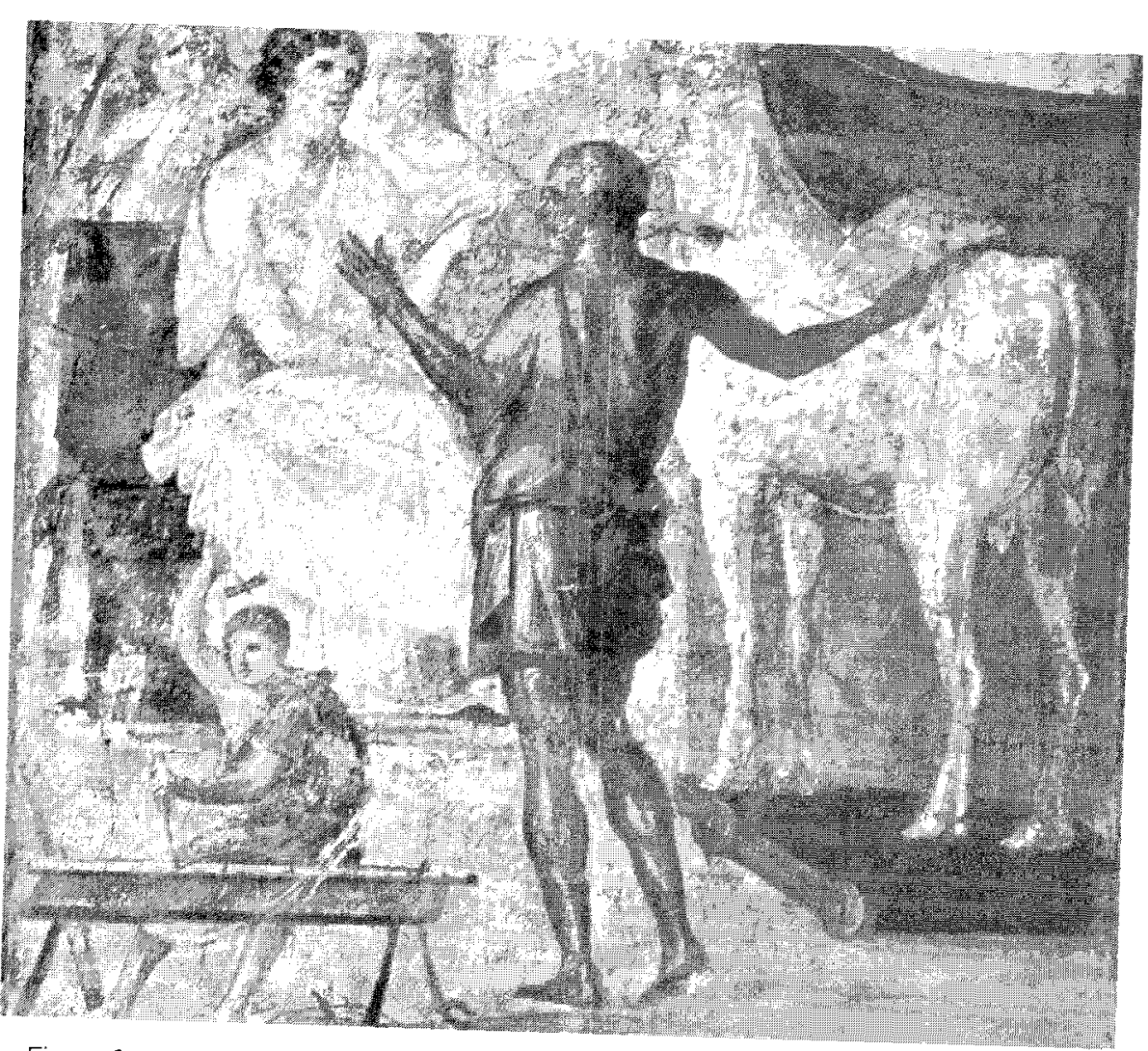

Figura 6. Dédalo presentando la vaca a Pasifae. Pintura de la Casa de los Vetii VI 15, 1 (p). Pompeya.

del citado sarcófago parisino, sin embargo la actitud del brazo en alto del artista, portando el martillo, indicaría que aún no esta totalmente terminado, como ocurre en el sarcófago, por consiguiente sería uno de los primeros momentos del episodio de Parsifae, tal como lo describe Philostrato refiriéndose a los cuadros que decoraban una villa de Nápoles (Imag. I c. 16). Esta escena de Dédalo construyendo la vaca también esta atestiguada, aunque con una iconograía diferente al pavimento tunecino, en un espejo etrusco de bronce que se conserva en el Cabinet des Médailles de Paris, fechado en el siglo IV-III a. C. ${ }^{14}$. Dédalo aparece también sentado y

\footnotetext{
14 D. Rebuffat-EMmanuel, Le miroir étruque daprès la collection du Cabinet des Médailles, École Française de Rome, Roma 1973, 250-252, n50; 417-418, lám. 50.
} 




Figura 7. Dédalo presentando la vaca a Pasífae. Pintura de la Casa de la Caza Antigua. Museo Nacional de Nápoles. Foto G. López Monteagudo.

tampoco existe ninguna referencia arquitectónica que aluda al taller del artista; tiene aspecto juvenil y esta acompañado de dos encargados, sosteniendo en su mano izquierda la vaca y en la derecha un cuchillo ( $\mathrm{Fi}$ gura 12). El mismo modelo iconográfico de Dédalo sentado y con la vaca, se documentaba en una pirtura pompeyana ( $V 2,9-12 n)$, hoy destruida ${ }^{15}$, el artista se encuentra en su taller, como indica la arquitectura del lugar, sosteniendo un pequeño modelo de vaca que enseña a Parsífae (Figura 13).

La reina cretense aparece también en los otros dos pavimentos, uno hallado en Argelia y el otro en Hispania. En el mosaico argelino de Macomades (Mrikeb-Thala), de finales del siglo III o principios del IV, aparece el

15 S. REINACH, op. cit. nota 4, 183,4; K. SCHEFOLD, op. cit. nota 4, 72. 



Figura 8. Pasifae encargando la vaca a Dédalo, la construcción de la vaca, Dédalo
ofreciendo la vaca a la reina. Sarcófago del Museo del Louvre.

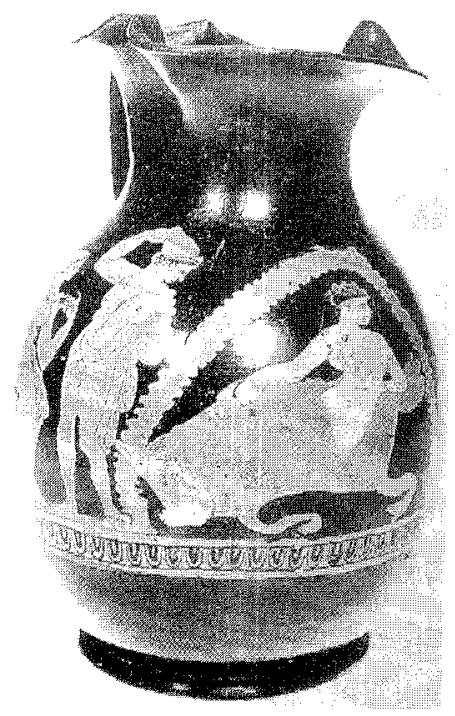

Figura 9. Pasifae introduciendose en la vaca. Oinochoe ático. Museo Clásico de la Universidad de Tasmania.

el momento en que Dédalo ofrece la vaca a Pasífae ${ }^{16}$. En un sólo plano, de izquierda a derecha, se representa Dédalo barbado, de perfil, sentado

is P. Wuilleumier, Musée de Algérie et de Tunisie, Musée d'Alger, suppl. Paris 1928, 79; J LAssus, Réflexions sur la tecnique de la mosaïque. París, 1957,35 , fig. 23; K.M.D. DunBaBIN, The mosaics of Roman North Africa, Oxford 1978, 25 nota 48, 44 y 265. 


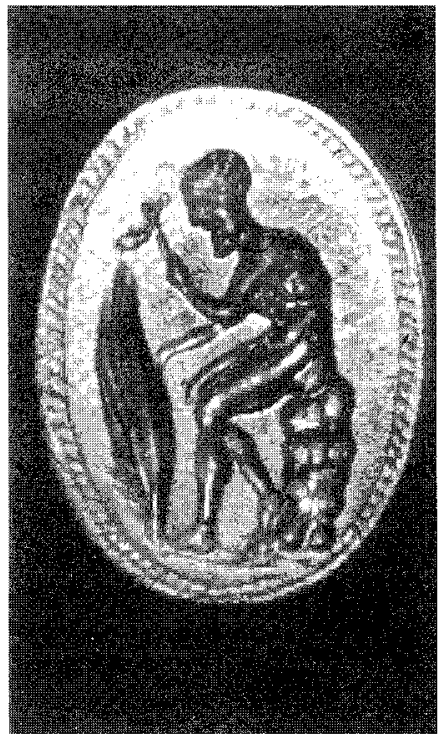

Figura 10. Dédalo confeccionando las alas. Entalle de cornalina. Museo Danicourt. Péronne.

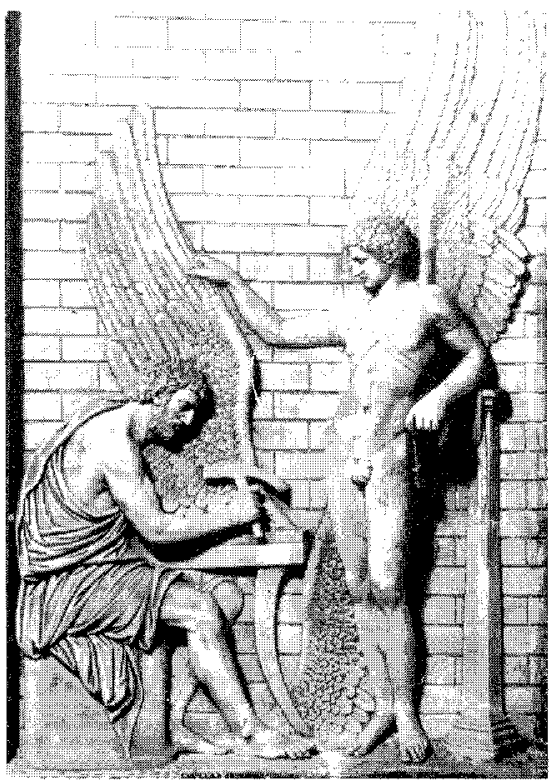

Figura 11. Dédalo e ĺcaro confeccionando las alas. Relieve de la Villa Albani. Roma. 


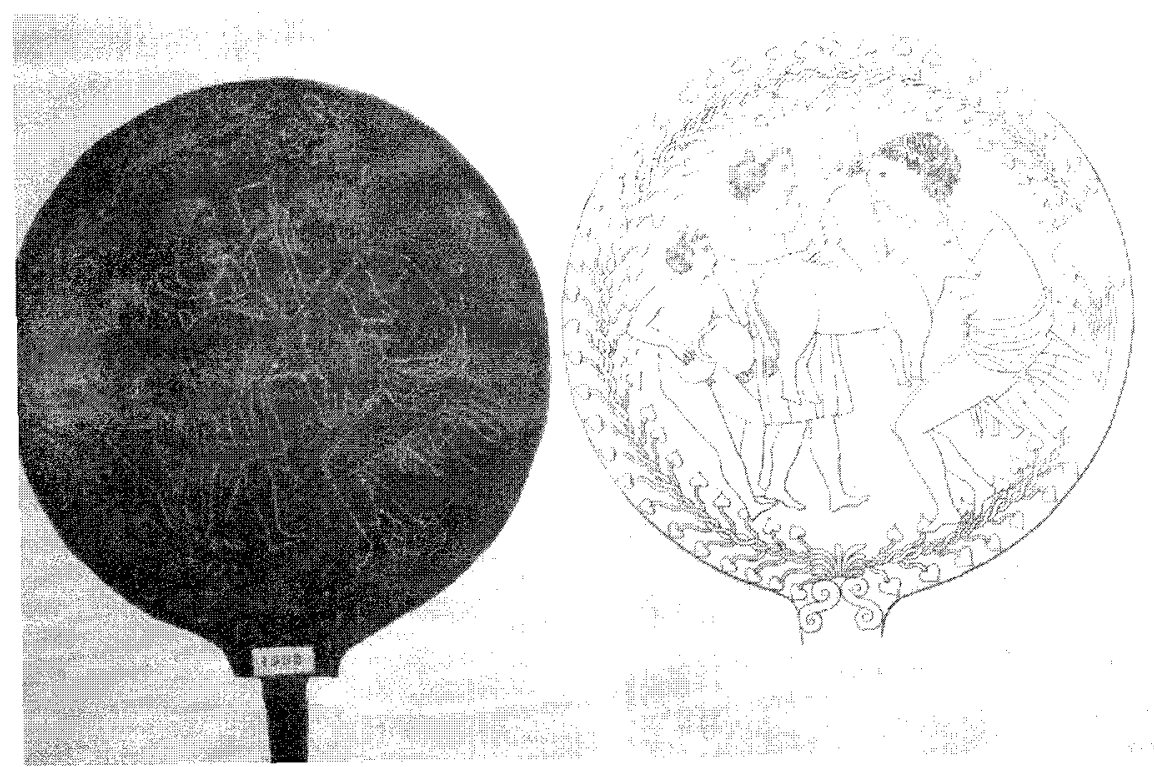

Figura 12. Dédalo confecionando la vaca. Espejo etrusco de bronce. Cabinet des Médailles de Paris.

vestido con túnica corta, exomis, e himation, en la mano izquierda lleva un martillo como el citado panel de Cartago, mientras con la derecha señala la vaca a Parsifae. La vaca esta vista de lado y tiene representada, al igual que en el mosaico tunecino, la trampilla $A$ su lado la reina viste largo chiton e himation drapeado cubriéndola la cabeza; no existe ninguna referencia arquitectónica (Figura 14).

Los paralelos más exactos de este pavimento se documenta en el relieve de mármol del Palacio Spada de Roma, fechado en época de Hadriano/ Antonino ${ }^{17}$, y en el de la urna funeraria procedente de Tívoli que se conserva en el Museo Nacional Romano, fechado en el siglo $1{ }^{18}$. En el primer ejemplar figura, como en el pavimento argelino, el grupo de Dédalo. Pasífae y la vaca, esta úitima representada de tres cuartos (Figura 15). La escena que ilustra la urna es más narrativa que los anteriores ejemplares y aparece, detrás del grupo, el toro, así como un eros entre este

\footnotetext{
17 E. Pottier, Daedalus, en DAREMBERg y SAglio, Dictionaire des Antiquites grécques et romaines, Paris 1900, 1. 11, 4, fig. 2277; F. WICKHOFF, Roman Art: Some of its Principles and Their Aplication to Early Chistian Painting, 1900, 74, fig. 26; E. Simon, EncVirg. III, 1987, 1006.

s F. Sinn, Stadtrömische Marmorurnen, Mainz Am Rrin 1987, 200, nº 456, lám. $70 f$.
} 


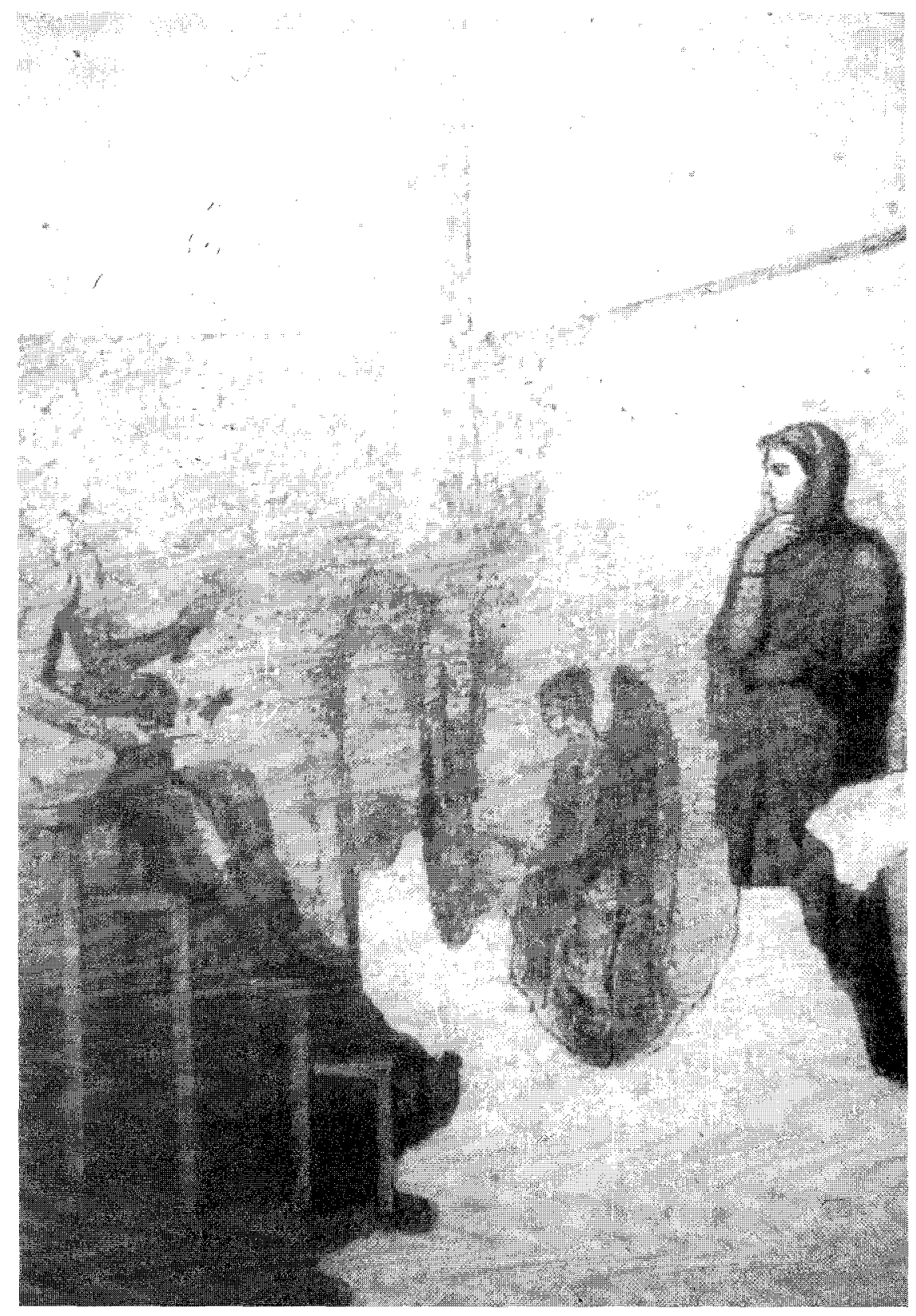

Figura 13. Dédalo en su taller le enseña a Pasifae un pequeño modelo de vaca. Pintura de Pompeya V2, 9-12(n). 


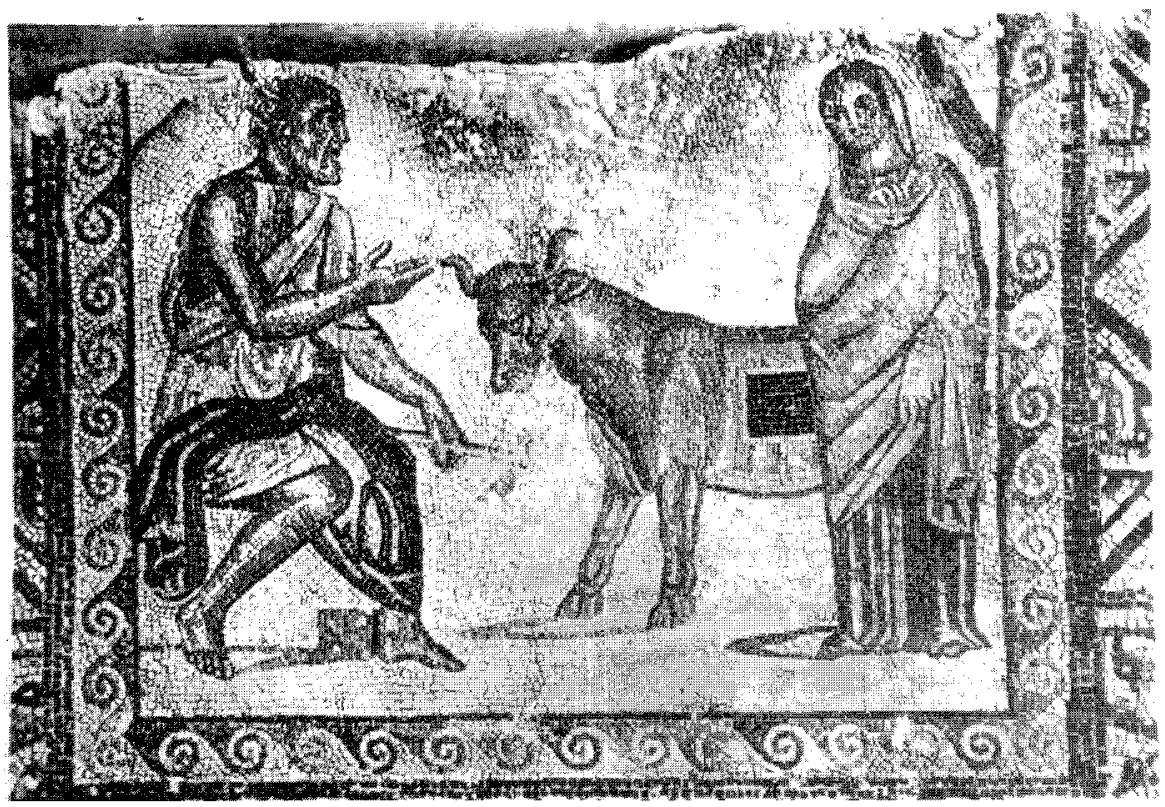

Figura 14. Dédalo ofreciendo la vaca a Pasifae. Mosaico argelino de Macomades (Mrikeb-Thala).

animal y la reina cretense, simbolizando la pasión amorosa (Figura 16). El hacha que Dédalo porta en su mano izquierda en el mosaico argelino es otro de los instrumentos típicos del artista, apreciándose igualmente en el mosaico lucense (vid. infra). La vestimenta de la reina, es la más usual dentro del arte tanto del mundo etrusco como del romano ${ }^{19}$.

El mosaico hispano de Lugo, la antigua colonia Lucus Augusti, del siglo III-medidos del IV ${ }^{20}$, ofrece, aunque desgraciadamente se encuentra muy deteriorado, un enorme interés iconográfico al conjuntarse en una solo cuadro varias facetas o etapas del relato mítico (Figura 17). En la parte superior-izquierda aparece Dédalo barbado, de perfil, sentado en un taburete o banqueta rudimentaria de gruesas patas, viste su usual túnica corta, exomis, calza caligae atadas con cordones, en su mano derecha lleva un hacha, que recuerda al representado en el mosaico de Macomades (vid.

19 Cf. LIMC VII, Pasiphae, $\mathrm{n}^{\circ}$ 7, 8, 15-17, 22, 23, 26, 29-31.

20 M.P. San Nicolás Pedfaz, Mosaico con escena mitológica hallado en Lugo (España), Actes du VIII Colloque Internacionale de la Mosaïque Antique (Lausanne, Suiza 1997). En prensa. 


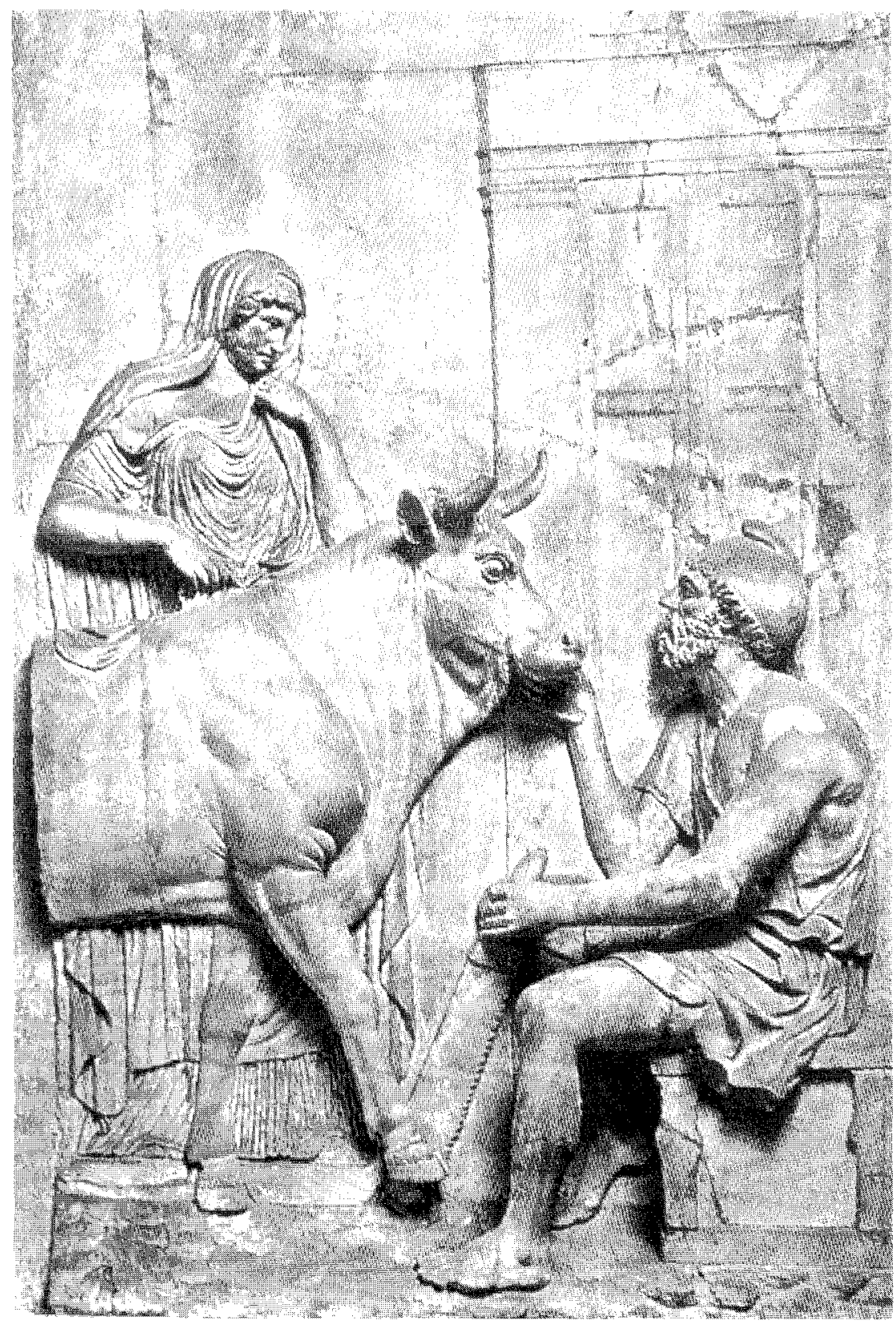

Figura 15. Dédalo ofreciendo la vaca a Pasífae. Relieve de mármol del Palacio Spada de Roma. 


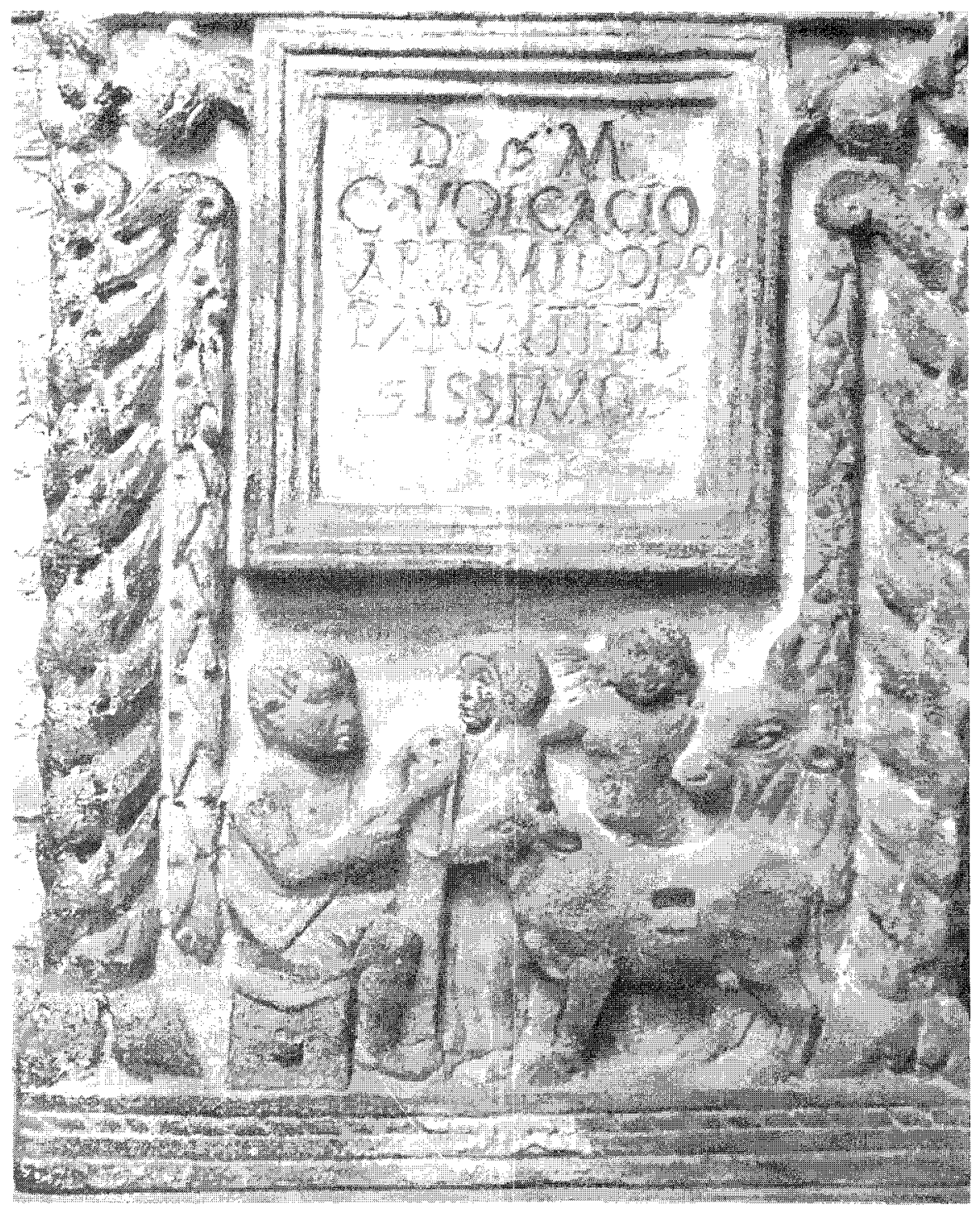

Figura 16. Una funeraria de Tivoli. Museo Nacional de Roma. 


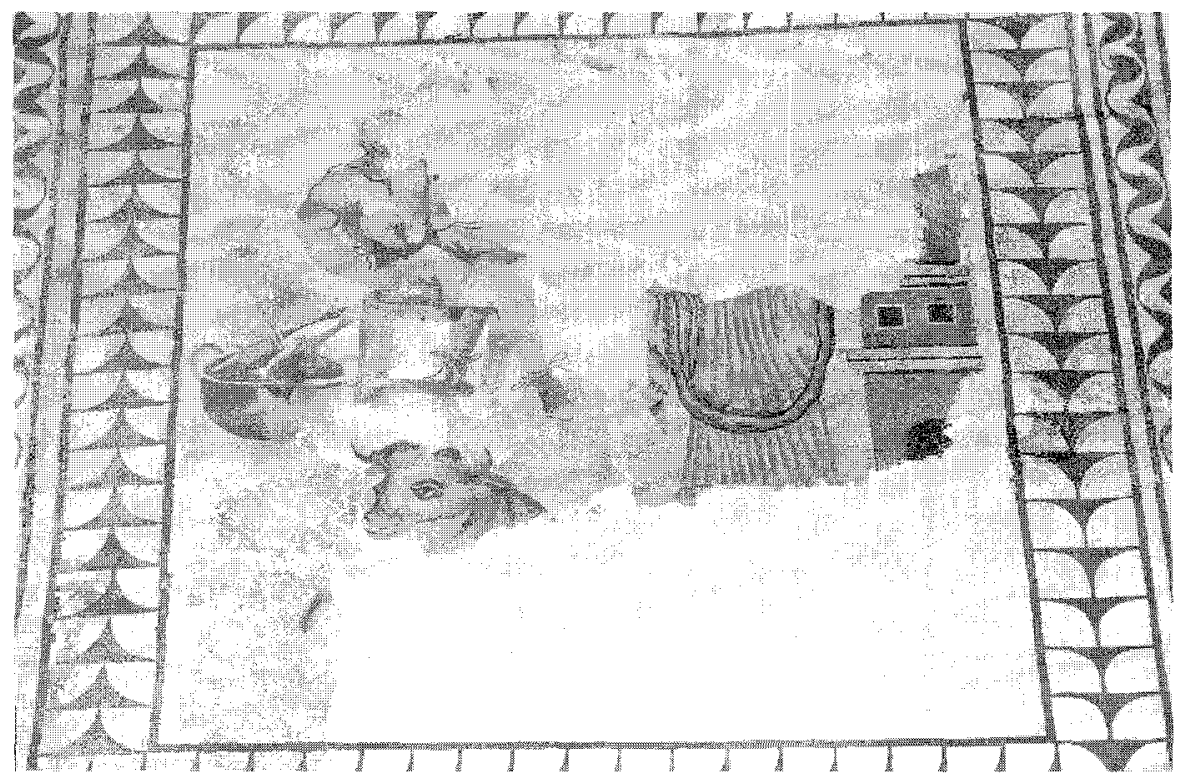

Figura 17. Mosaico de la colonia Lucus Augusti. Foto del Museo Arqueológico de Lugo.

supra). La actitud de la mano izquierda, que sujeta, ayudado con ambas piernas, un madero o piel en forma de bóvido, cuyos paralelos más próximos aparecen en dos ejemplares ya citados, el espejo de bronce del Cabinet de Médailles de Paris y en la desaparecida pintura pompeyana (V2, 9-12n); así como el recipiente o cesto de asas, situado a su derecha y figurado también en el pavimento de Henchir-Thina (vid. infra), con los instrumentos artesanales (gubia, azuela y maza) ${ }^{21}$, todos estos detalles iconográficos ofrecen las características de encontrarse el artista en su taller construyendo la vaca, que sería el primer momento de la escena del pavimento, reflejando el mismo momento que el citado panel no 25 del mosaico de los Caballos, pero utilizando la variante versión iconográfica de estar ensamblando el madero o confeccionando la piel. Algunas urnas etruscas muestran igualmente la fabricación del bóvido, por piezas, en el taller de Dédalo, en presencia o no de Pasifae ${ }^{22}$ (Figura 18).

${ }^{21}$ Estos utensilios figuran junto a Ícaro en un espejo etrusco de bronce, de finales del siglo $\mathrm{V}$ principios del li a.C., cf., G.M.A. HaNFMANN, Daidalos in Etruria, AJA 39, 1935, 192, nota 6.

22 A. Brum y G. Korre, I rilievi delle ume etrusche, t. II, Roma 1890 79-80, láms. 28, 1-2 (y fig. de portada); F. BASTEt-H. BRunsting, Corpus signorum Classicorum Musei Antiquarii LugdunoBatavi, 1982, 157, lám. 79; LIMC VII, Pasiphae, $\mathrm{n}^{0} 8$ y 10. 
En un plano más inferior existe restos de la figura de Parsífae, vista de frente, vistiendo su usual túnica larga con pliegues e himation; delante de ella aparece representado, aunque muy deteriorado, un bóvido, cuyos rasgos naturalistas y actitud briosamente galopante indican que es un toro en vez de la vaca, tipo iconográfico que se repite en el mito de Europa, en las pinturas pompeyanas y particularmente en los emblemas musivos como los de Mérida, Tivoli, Fossombrone, Arlès, fechados en los siglos $\|$ y $11{ }^{23}$, sugiriendo una segunda escena en el pavimento hispano, que la reina ya ha experimentado el sentimiento de atracción amorosa por el toro. Por otra parte, el movimiento de los pies de Pasifae danzando, preludia la realización de la cópula, como si fuese una danza matrimonial; mientras que Dédalo seria el organizador de esta unión que tiene todo el aspecto de una hierogamia, Pasifae es la reina cretense, el toro, símbolo de realeza, es enviado por Poseidon o por Venus, y tuvo un importante papel en la historia de Creta ${ }^{24}$.



Figura 18. Dédalo construyendo la vaca. Urna etrusca de Volterra. Museo de Guarnacci.

23 O. WATtEL-DE CrolzANT, Les mosaigues représentant le mythe d'Europe (1-vi siècles), Paris 1995, 119, 127-128. 141-143, 149-150, 163-165, láms. XIlb, XIVc, XVa, XVIa, XIXa ; G. López Monteagudo-M. P. San Nicolás Pedaaz, El mito de Europa en los mosaicos hispano-romanos. Análisis iconográfico e interpretativo, Espacio, Tiempo y Forma, Serie 11, t. 8, 1995, $411-414$.

24 Para el culto al toro cf., M. RICE. The power of the Bull, Londres y Nueva York 1998, concretamente en Creta pp. 198-219. 
Finalmente a la izquierda del grupo se alza restos de una torre rectangular de tres pisos separados por cornisas, con puerta de entrada arqueada y dos ventanas cuadradas en el segundo piso, que la identificamos con el Laberinto, el famoso edificio construido por Dédalo para encerrar al bestial Minotauro, ya sea como una nueva iniciativa del artista para ayudar a Parsífae (Hig. fab. 40) o por mandato del propio Minos (Apol. III 1, 4; Ovid. Met. 157-161), esta representación hace referencia al final del relato con la culminación de la zoofilia y el nacimiento de la bestia; fruto del adulterio y consecuencia indirecta del ingenio de Dédalo como señala Diodoro (IV 77).

La presencia del toro en el episodio de Dédalo, la vaca y Pasífae no es muy habitual y es exclusiva del arte romano, encontrándose en tres pinturas murales. En la pintura de la villa Tor Marancia, fechada en el siglo III y conservada en la Biblioteca Vaticana se representa solo el grupo compuesto de Pasífae y el toro ${ }^{25}$. La reina figura en perfil y de pie junto al bóvido, viste chiton y apoya cariñosamente su brazo derecho en el dorso del animal; encima de ellos, la inscripción latina PASIFAE rechaza cualquier duda de identificación (Figura 19). Las otras pinturas, una de la Casa del Bicentario de Herculano (Figura 20) y la otra de Pompeya (VI 14,43c) ${ }^{26}$, presentan el momento que la reina esta encargando la vaca en el umbral del taller del artista y en ambas aparecen la vaca y el toro.

Sin embargo, la composición más parecida al ejemplar hispano en cuanto a su contenido alegórico, se documenta en el relieve de la citada urna funeraria de Tívoli, donde se distingue también dos momentos diferentes del mito en una misma escena. A la izquierda Dédalo se encuentra sentado ofreciendo la vaca a Pasífae, escena similar a la del pavimento argelino y la pintura pompeyana; mientras que a la derecha, detrás de ellos, aparece la cabeza del toro girada hacia la izquierda, contemplando la escena, y tiene el gesto complaciente como en la pintura de Tor Marancia, a la vez que se le aprecia un rictu pícaro. Entre el animal y la reina cretense aparece un eros, al igual que en la citada pintura pompeyana ( $V 2,9-12 n)$ cuando la reina le encarga la vaca a Dédalo, como símbolo del proceso amoroso que conducirá a la cópula. Este detalle iconográfico que proporciona a ambas escenas el contenido erótico del mito podría haber estado también figurado en el mosaico lucense.

S. REINACH, op. cit. nota 4, 183,2; EAA V, Pasife, 983, fig. 1199; LIMM VII, Pasiphae, no 1.

26 A. MALPI, Ercolano. I nuovi scavi (1927-1958) I, 1958, 231, fig. 181; K. SCHEFOLD, op. cit. nota $4,138$. 


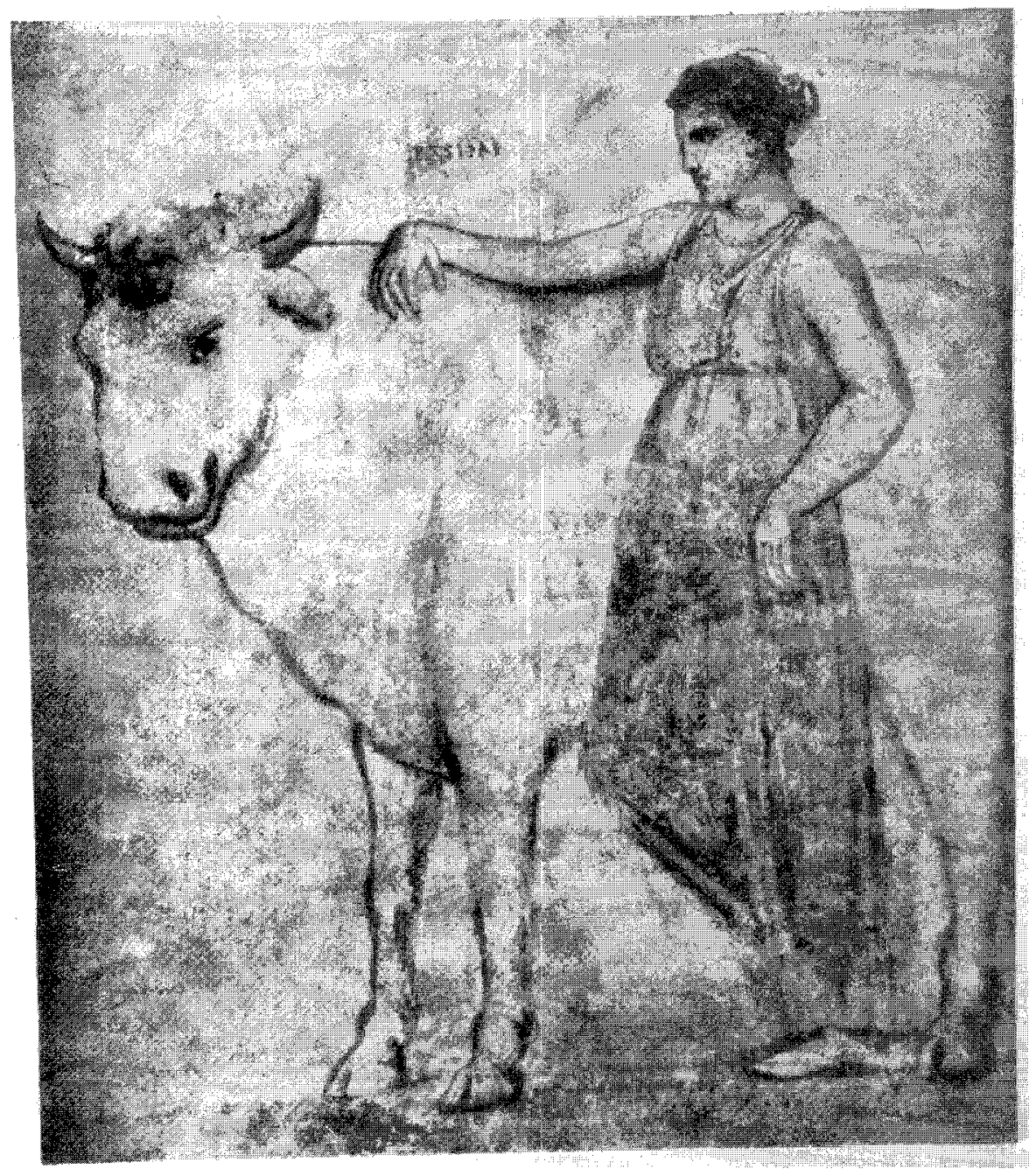

Figura 19. Pasifae y el toro. Pintura de la villa Tor Marancia.

La presencia del Laberinto constituye un unicum en este tipo de representaciones, pero con él se ha querido señalar otra de las obras de Dédalo, lugar donde fue encerrado junto a su hijo Ícaro y que fue construido para albergar al mítico Minotauro. En este último sentido, podría sintetizar el fruto de la zoofilia, supliendo la ausencia iconográfica del niño-monstruo que aparece en las urnas, cuando Minos le descubre (Figura 21) y en otros ejem- 




Figura 20. Pasifae encargando la vaca a Dédalo. Pintura de la Casa del Bicentario de Herculano.

plares etruscos como en la copa que se conserva en el Cabinet des Médailles de Paris, con Pasífae sosteniendo al niño en su regazo (Figura 22) ${ }^{27}$.

27 A. Brum y G. KörTe, op. cit. nota 22, 81-82, lám. 29, 4 y 5; F. H. PiRault, Recherches sur quelques séries durnes de Volterra à représentations mythologiques, Roma 1972 lám. 31; 




Figura 21. Minos descubriendo al niño Minotauro. Urna etrusca de Volterra. Museo de Guarnacci.

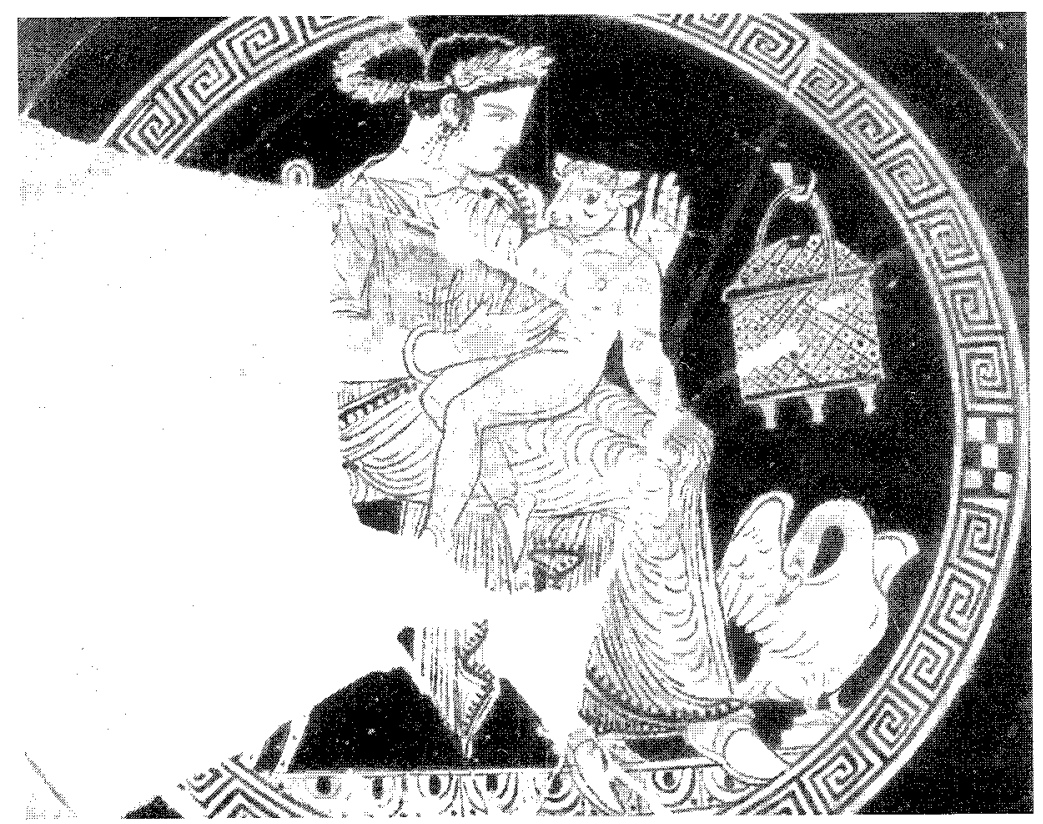

Figura 22. Pasífae con el niño Minotauro en su regazo. Copa etrusca. Cabinet des Médailles de Paris. 
Aunque la estructura arquitectónica del edificio es bastante imprecisa en las obras de los autores antiguos (Plinio Nat. Hist. XXXVI 19, 85; Diod. I, 97; Virg. En. V, 588 ss; Apol. III 1,4), en las figuraciones del arte antiguo se representa como un espacio real. Como edificio figurado aparece ya en los vasos áticos de figuras negras y rojas de los siglos $v 1$ y $\vee$ a. C. con el tema de Teseo y el Minotauro, y en ellos se representa el Laberinto por medio de columnas y de frontones para representar la entrada del monumento, incluyéndose en algunos ejemplares una banda geométrica a base de meandros y ajedrezado en forma de damero, que simbolizaría la estructura interior ${ }^{28}$ (Figura 23). En la musivaria romana aparece en seis ejemplares como fondo de la escena de la lucha del héroe con el

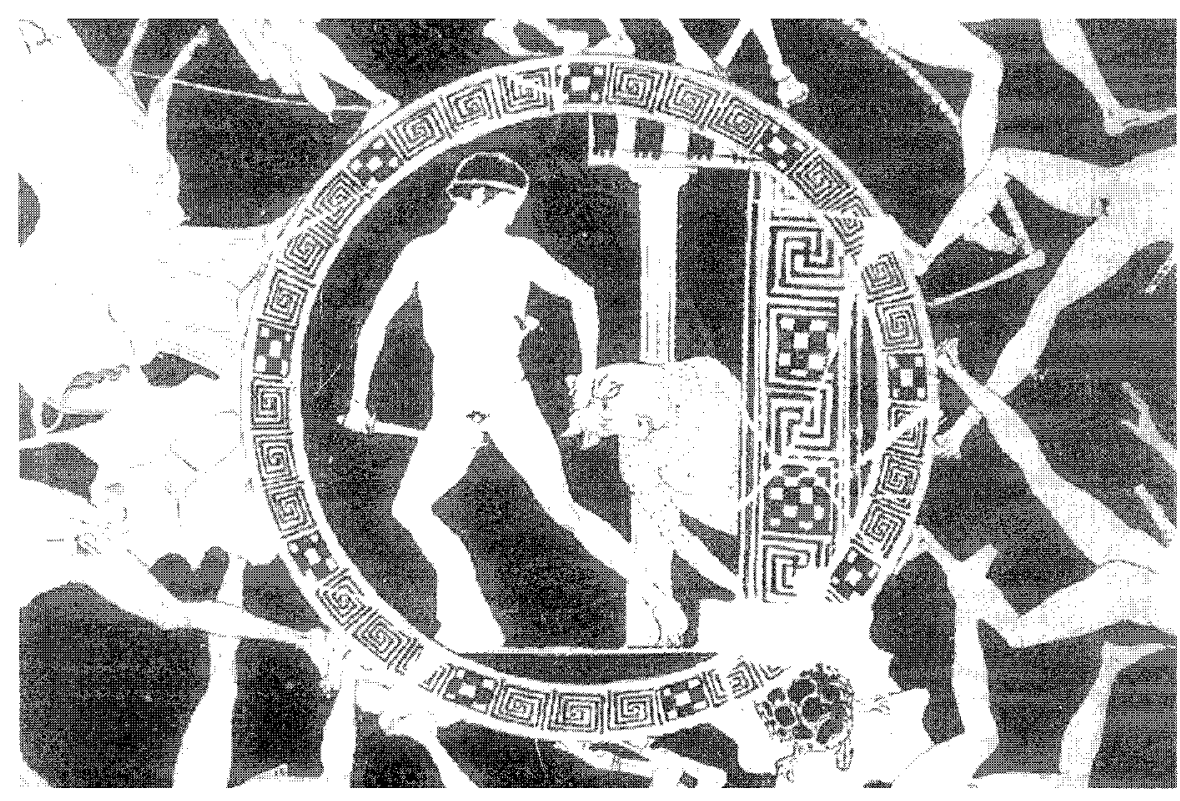

Figura 23. Teseo vencedor del Minotauro. Copa ática de Vulci. British Museum.

G. Catenl, Volterra. Museo Guarnacci, 1988, fig. 16; LIMC VI, Minos I, no 2-7; Minotauros, nº 41 y 42; LIMC VII, Pasiphae, $\mathrm{n}^{2} 25$ y 26.

28 LIMC VII, Theseus, no 46 y 47,52; F. Dízz DE Velasco, Lenguajes de la Religión. Mitos, símbolos e imágenes de la Grecia Antigua, Madrid 1998, 43-45, 52-53, notas, 5-6, 10-11, 32-38, ilustraciones $9,11,18-20$. En las monedas de Cnosos aparece el Laberinto de diversas formas, cf., G. LE RIDER, Monnaires crétoises du Ve au ler siècle avant J.C., Paris 1966. En un grafito de la Casa de Lucrezio en Pompeya se ha representado un Laberinto cuadrangular con la inscripción Labyrinthus hic habitat minotauris, cf. E. POTTIER, op. cit nota 17, Labyrinthus, 882-883, fig. 4317. 
monstruo ${ }^{29}$; figurando un edificio rectangular con ventanas cuadradas como en el pavimento lucense se representa en el mosaico de de Torre de Palma (Portugal), del siglo $\mathrm{II}^{30}$ (Figura 24), mientras que la puerta abobedada aparece en el mosaico italiano de Castellone i Mola di Gaete, fechado hacia el 100-90 a.C.(Figura 25) y en el de Gurgi (Libia), de finales del siglo $\|$ o principios del III (Figura 26), así como en el ejemplar pompeyano



Figura 24. Teseo luchando con el Minotauro. Mosaico de Torre de Palma. Portugal.

29 W. A. DASZEWSKl, op. cit. nota 7, 64, láms. 26 y 27, 33a-b, 34a-b, 36.

30 J. M. BairRao Oleiro, O tema do Labirinto nos Mosaicos portugueses, CMGR VI (PalenciaMérida 1990), 1994, págs. 273-244, figs 1 y 2. 


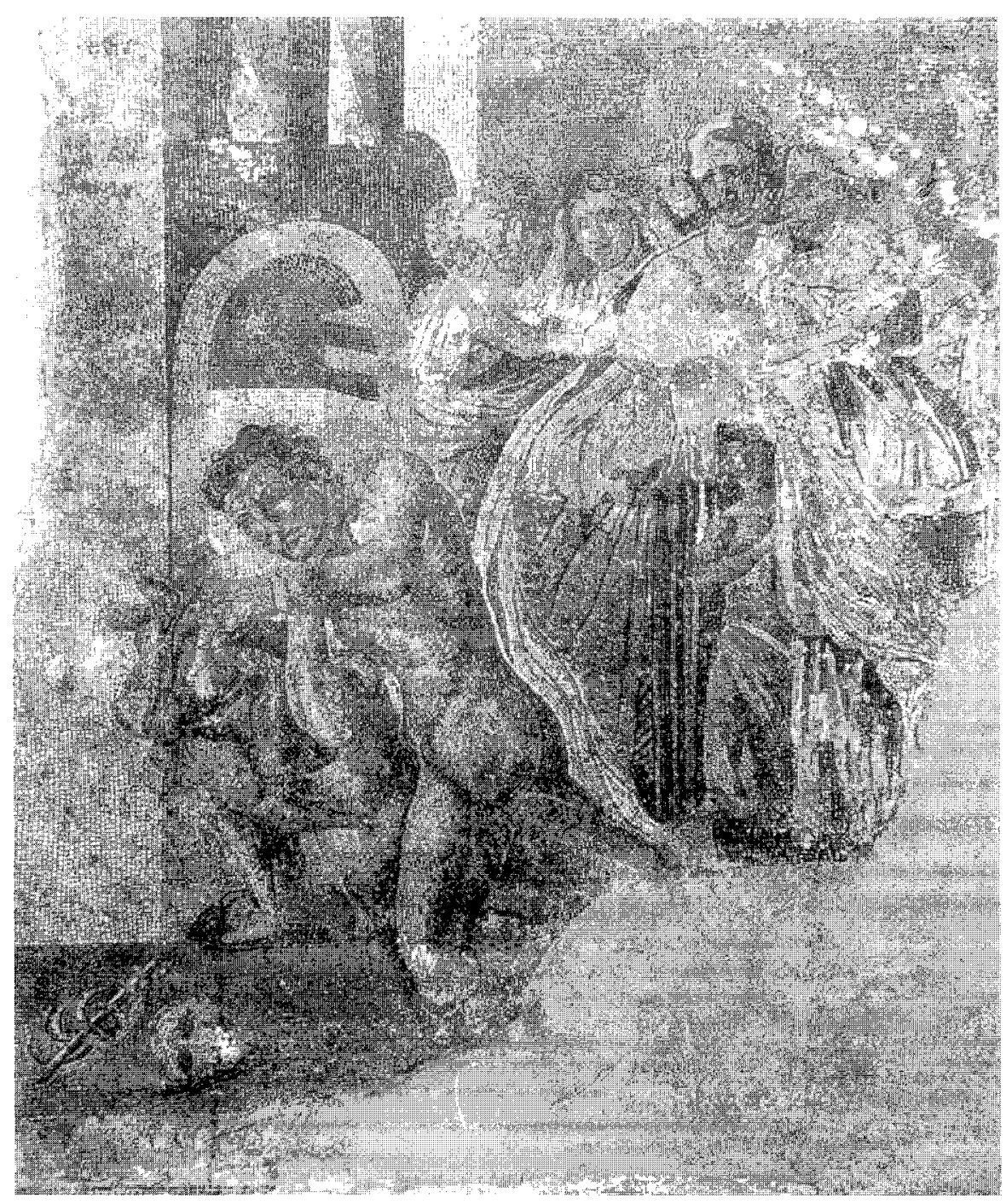

Figura 25. Teseo luchando con el Minotauro. Mosaico de Castellone e Mola di Gaete. Museo Nacional de Nápoles.

del Museo Nacional de Nápoles, en donde se muestra también una ventana (Figura 27).

Una escena excepcional del arte romano, en la que se ha supuesto la figura de Dédalo y su relación con el tema del Laberinto, se representó en 


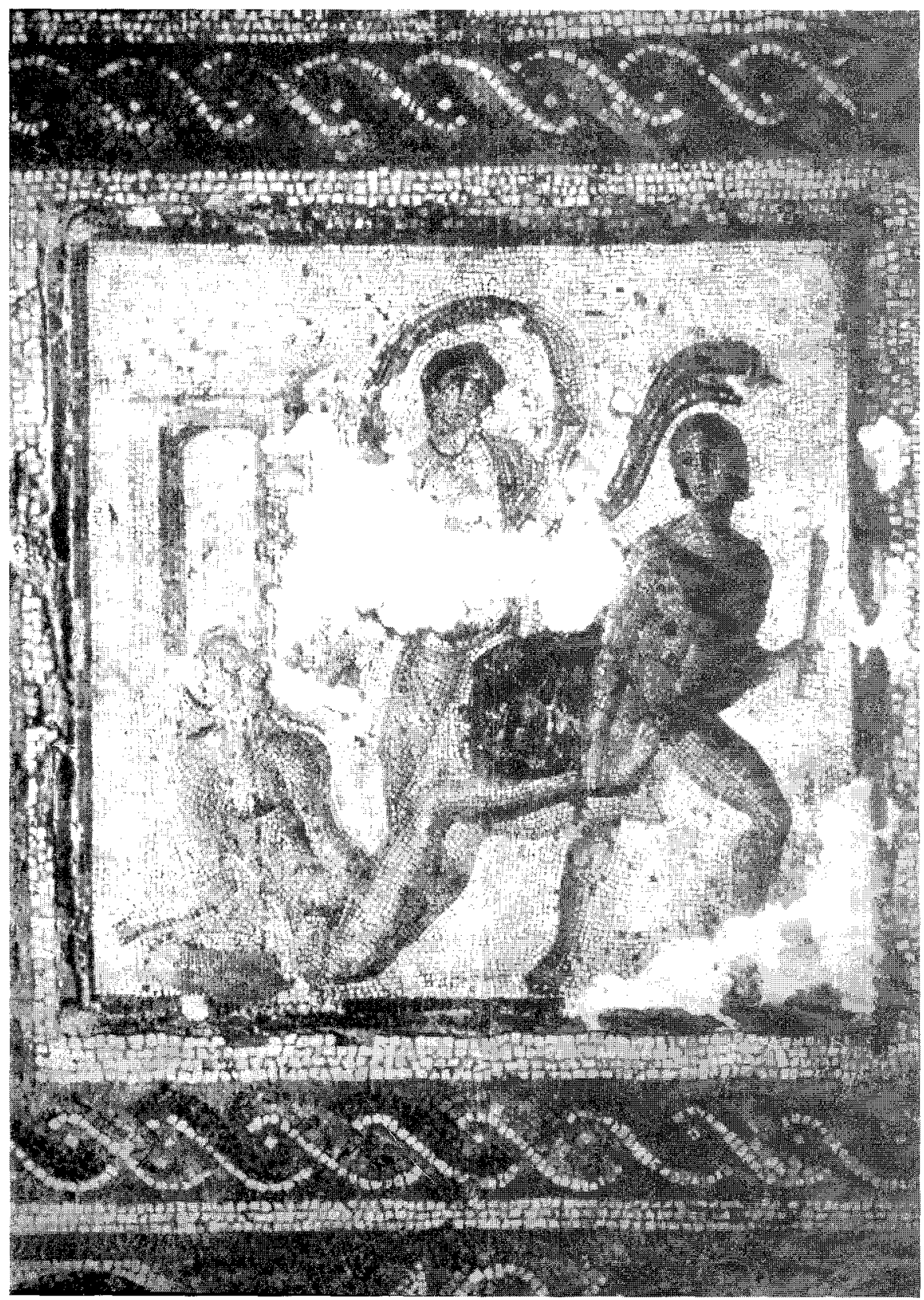

Figura 26. Teseo vencedor del Minotauro. Mosaico de Gurgi. Museo de Tripoli. 
una pintura de la Casa del Criptoportico Od Omerica de Pompeya. (I 6, 24), fechada en época de Verpasiano ${ }^{31}$. El artista ofrece a Ariadna el plano del edificio; en medio se de ambos personajes una Victoria con una palma en la mano derecha, símbolo del triunfo de la hazaña que realizará Teseo



Figura 27. Teseo luchando con el Minotauro. Mosaico de Pompeya. Museo Nacional de Nápoles.

(Figura 28). Este episodio uniría el mito del ingenioso Dédalo, constructor del monumento, con la empresa del héroe.

Otra secuencia de la historia del artista se representa en el panel no 9 del pavimento de los caballos de Cartago ${ }^{32}$. Delante del équido, aparece Dédalo de pie, vestido con túnica corta y clavi que se sujeta en el lado izquierdo; en la mano izquierda lleva un martillo como en el otro panel del mismo mosaico; y con la derecha levantada, señala a ícaro que esta representado, en la parte superior, volando complacido hacia la izquierda y con el rostro girado a la derecha, mirando a su padre (Figura 29).

31 V. Spinozzola, Pompei. Alla Luce degli savi nuovi di Via dell Abbondanze (Anni 1910-1923), Roma 1953, 517-519, fig. 578, lám. XXXb; LIMC III, Ariadne, nº 163.

32 J.W. Salomonson, op. cit. nota 8, 99-100, fig. 13, lám. XLVI, 3. 




Figura 28. Dédalo ofreciendo el plano del Laberinto a Ariadna. Pintura de la Casa del Criptopórtico Od Omerica de Pompeya 16, 2-4.

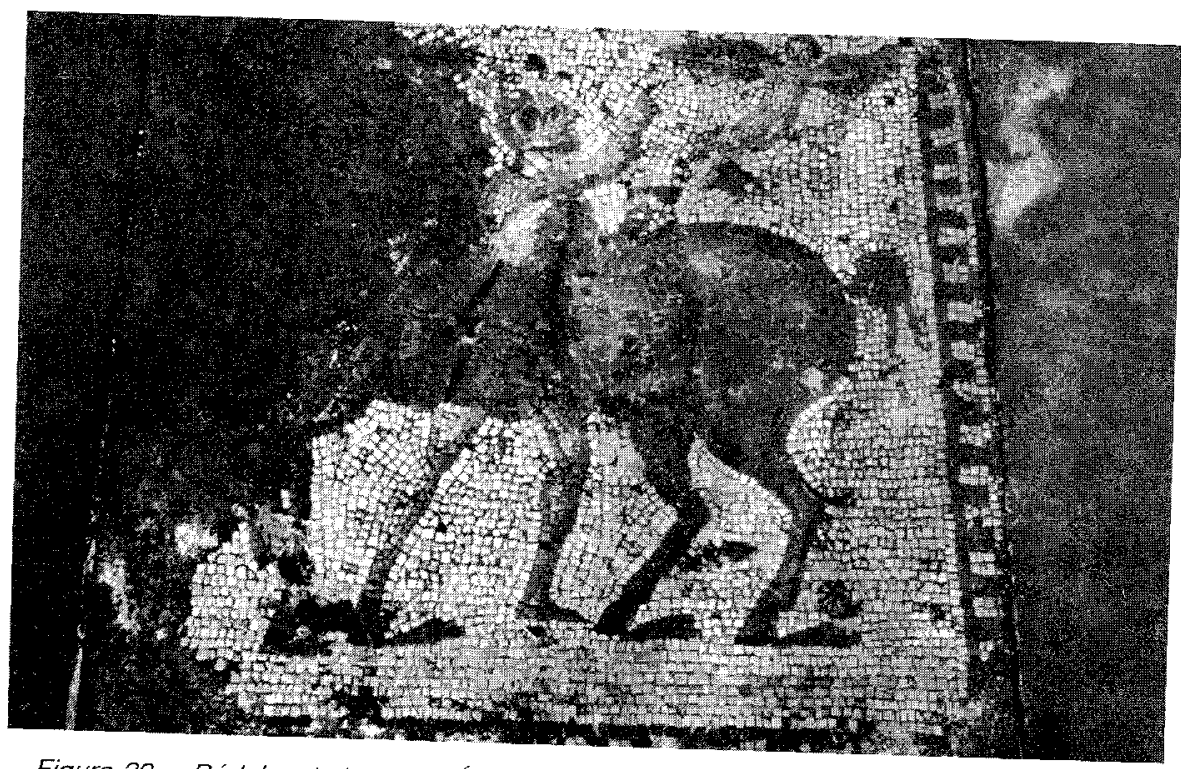

Figura 29. Dédalo y la huida de ĺcaro de Creta. Mosaico de la Casa de los Caballos de Cartago. Panel n 9. Foto in situ de G. López Monteagudo. 
No cabe duda que la escena que aquí se representa es el momento de la huida de Ícaro de Creta, que emprende el vuelo con las alas fabricadas por su padre, pero no si antes ser aconsejado por este de que no se acercase demasiado al sol para evitar que el excesivo calor despegase las alas, ni tampoco demasiado bajo para que la humedad no las dañase como señalan Apolodoro (II 6, 3) y Ovidio (Ars II, 61; Met. VIII, 204). Por consiguiente, este mosaico seria la secuencia anterior al vuelo del artista como se ha figurado en una ánfora griega hallada en Italia, de mediados del siglo vI a. C. ${ }^{33}$, en la cual padre e hijo ya están volando por los aires (Figura 30); iconografía que perdura en un bajorrelieve del siglo XIV



Figura 30. Dédalo e ĺcaro volando. Ánfora griega. Italia.

de A. Pisano, que decoraba el campanario de Giotto en la catedral de Florencia, conservado en el Museo de la Opera di Santa Maria del Fiore ${ }^{34}$, con la figura de Dédalo en el momento de emprender el vuelo (Figura 31). Todos estos ejemplares ilustrarían iconograficamente los preliminares del fallo de ícaro y su fatal desenlace, tema habitual en las escenas de las pinturas pompeyanas ${ }^{35}$ (Figuras 32-33).

33 K. Schauenburg, en Classica et Provincialia, 1978, 169-176, lám. 59; LIMC III, Daidalos et Ikaros, $\mathrm{n}^{\mathrm{g}} 31$.

34 L. Becherucci, Andrea Pisano nel campanile di Giotto, Milan 1965, Lám. 16.

35 S. REINACH, op. cit. nota 4, 183, 6 y 7, 184, 1 y 4; K. SCHEFOLD, op. cit. nota 4, 72, 31, 46, 89, 348; LIMC III, Daidalos et Ikaros, n $36-43$. 


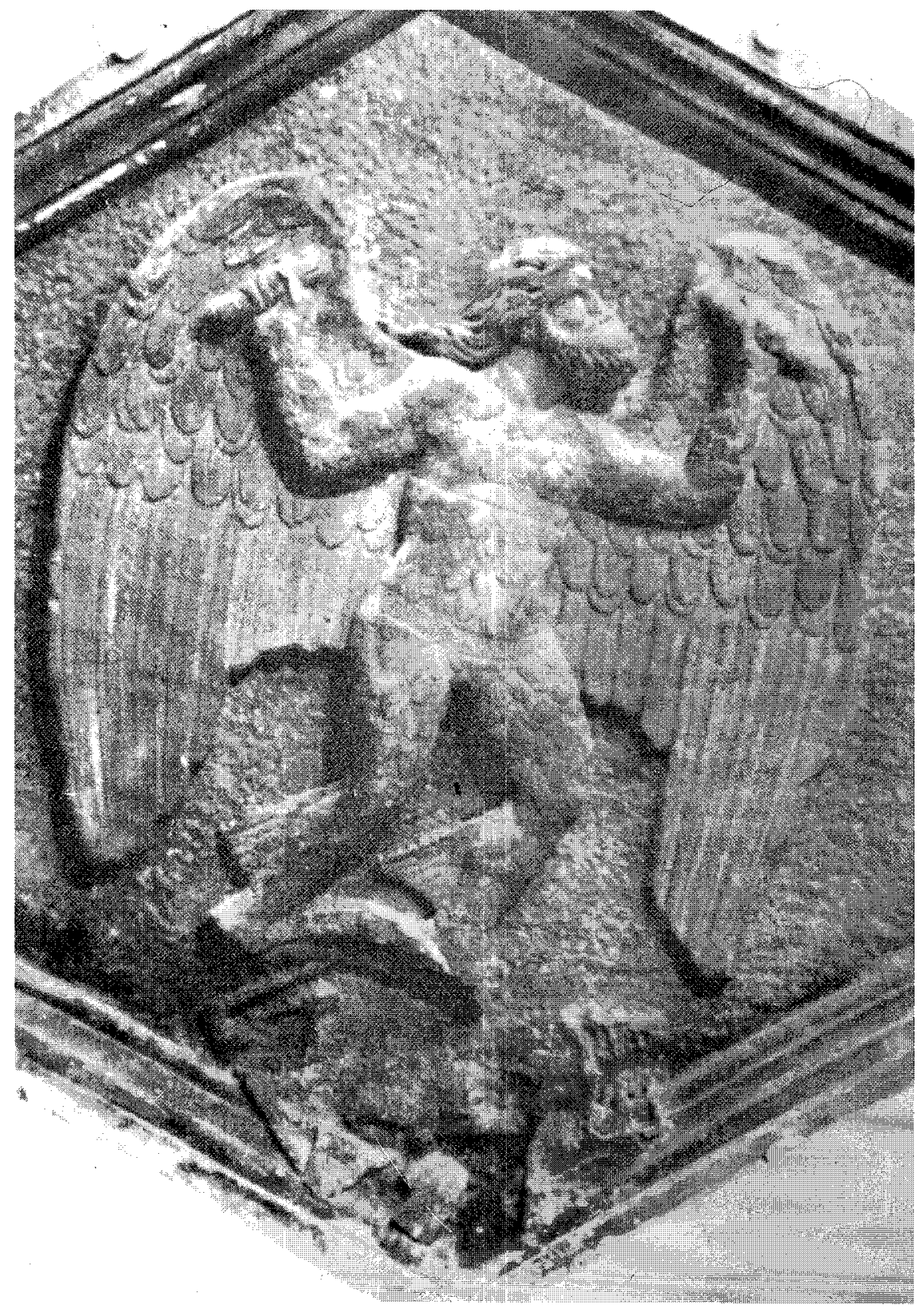

Figura 31. Dédalo volando. Bajorrelieve de A. Pisano, procedente del campanario de Giotto. Florencia. Museo de la Opera di Santa Maria de Fiore. 




Figura 32. La caída de ícaro. Pintura de la Casa del Sacerdote Amandus 17, 7. Pompeya. 


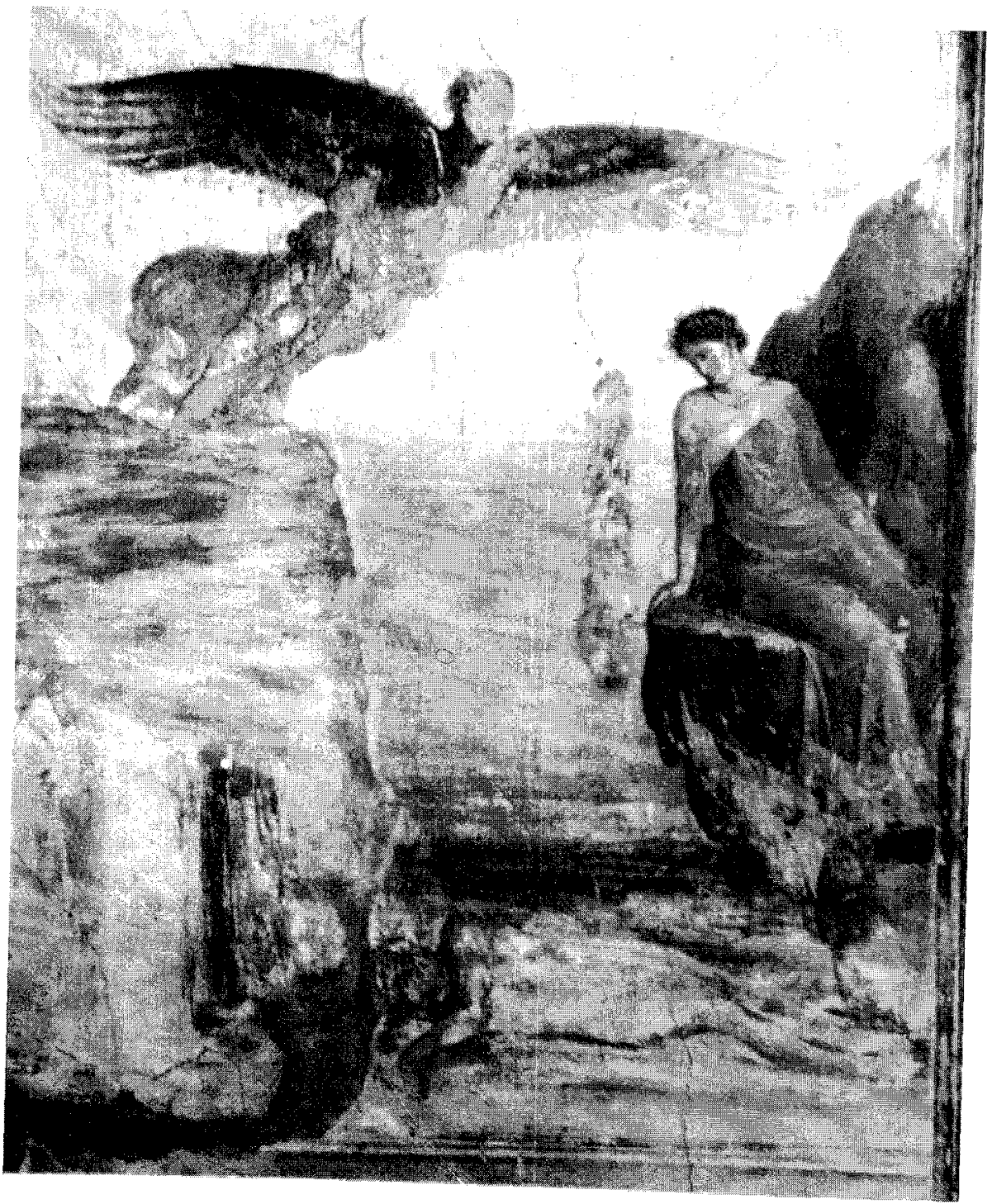

Figura 33. Muerte de Ícaro. Pintura de la Villa Imperial. Pompeya. 
En el mosaico circular del frigidarium o estancia C, 4 de las Grandes Termas de Thaenae (Henchir-Thina), de fines del siglo III, que se conserva muy fragmentado en el Museo de Sfax (Túnez), aparecen diferentes escenas marinas. Esta presidido por Arión cabalgando sobre el delfín y entre las figuraciones mitológicas aparecen: Venus en la concha, Scylla, Ulises y la sirenas, Selene y Endimión, Leandro y Hero, Perseo y Andrómeda o Hércules y Hesión, Dánae y Perseo, todas ellas con nereidas y tritones, aurigas en carros tirados por delfines, monstruos marinos, erotes, embarcaciones y pescadores ${ }^{36}$. En la parte derecha del pavimento está representado Dédalo de pie sobre una roca de la que brota una hierba, viste túnica corta sin mangas con el borde de color rojo, en la mano izquierda lleva una sierra mientras el brazo derecho esta levantado como en el panel $\mathrm{n}^{\circ} 9$ del pavimento de Cartago (vid. supra); junto al pie derecho figura un cesto con instrumentos de carpintería (Figura 34), que recuerda al representado en el mosaico lucense.

Esta figura masculina, la cual hemos identificado sin ninguna duda como Dédalo, podría estar aludiendo, aunque no esté representado Ícaro, la huida de Creta, como parece indicar el gesto de la mano levantada, hipótesis por otra parte reforzada al hallarse figurado en un pavimento con otros grupos mitológicos cuya relación es estrictamente el tema marino. En este contexto, y a diferencia con el anterior pavimento tunecino, cobraría un enorme interés el pasaje de Pausanias (IX 11, 4-5) y el de Diodoro (IV 77, 5-6) según los cuales padre e hijo habrían huido por mar, en embarcaciones de velas, habiendo inventado Dédalo las velas, pereciendo Ícaro en naufragio.

Estas versiones literarias que sustituyen el invento de las alas por la embarcación, estaría en relación con el carácter de Dédalo como constructor de navio que figura en un vidrio romano del siglo $\mathrm{IV}^{37}$, en el cual se representa Dédalo con aspecto habitual de hombre maduro y barbado, de perfil y sentado, trabajando la proa de un barco, acompañado por varios ayudantes que realizan diversos menesteres de carpintería, bajo la dirección de la diosa Athenea. En el centro, posiblemente el contratista, cuyo nombre, DEDALI en genitivo, aparece en la inscripción bordeando la escena (Figura 35). Igualmente el nombre de la madre de ĺcaro, Náucrate, esclava de Minos (Apol. IX 11, 4), surgiere esta actividad naval, aunque paradogicamente para él sea la muerte.

36 P. Gaukler, Inventaire des Mosaïques de la Gaule et de I'Afrique proconsulare (Tunisie), II, Suppl. A. Merlin, Paris 1910-1915, 9-13, no 18,C, 4a; R. MAssigl, Museé de Sfax, Paris 1912, 4, lám. III, 2; K.M.D. DuNBaBin, op. cit. nota 16, 273.

37 R. GARRUCCI, Vetri ornati di figure in oro trovati nei cimiteri dei cristiani primitivi di Roma, Roma 1858, 63, lám. XXXIII; F. FrontisI-DucrouX, op. cit. nota 1, 153, fig. XI. 




Figura 34. Dédalo. Mosaico de Henchir Thina (Túnez). Museo de Stax. 
A través del análisis de estos documentos arqueológicos puede decirse que, en la musivaria romana las escenas que documentan a Dédalo son escasas en comparación con las dedicadas al tema del Laberinto en relación con el mito de Teseo y el Minotauro que tienen un valor profilático ${ }^{38}$; sin embargo en ellos se aprecia distintas fases que completan las escenas dedicadas a su mitología: Dédalo en su taller confeccionando la vaca; ofreciendo la vaca ya terminada a Pasífae; y su anhelada huida de Creta con su hijo Ícaro. Este último pasaje parece estar documentado en sus dos distintas versiones literarias. No obstante, de todas estas representaciones la del mosaico hispano ofrece por sus particularidades iconográficas un



Figura 35. Dédalo confeccionando la proa de una embarcación. Vidrio con figuraciones en oro, Roma.

38 Tema que estamos elaborando para una próxima publicación. 
gran contenido alegórico que la diferencia de las restantes, siendo un unicum en la musivaria romana, no solo por el carácter narrativo de sus imágenes, en las que se conjuntan varios episodios del mito, más propio de otras documentaciones como las estelas o sarcófagos, sino en la forma de trabajar Dédalo el madero o piel en forma de bóvido, en la figuración del toro, elemento iconográfico escaso y peculiar de los documentos romanos, y en la presencia del Laberinto, ausente en este tipo de representaciones, que señala el otro invento de Dédalo y sintetiza el episodio de su cautiverio, a la vez que lo enlaza simbólicamente con el episodio de Teseo.

En este sentido y del análisis de los diferentes detalles iconográficos que hemos señalado, pensamos que las escenas de la musivaria romana muestran que los domini, propietarios de estos pavimentos, tenian un buen conocimiento o gusto por la mitología en sus distintas versiones literarias grecorromanas. 